\title{
NEW MULTIFUNCTIONAL AGENTS AND THEIR INHIBITORY EFFECTS ON THE ACETYL CHOLINESTERASE ENZYME
}

\author{
Ali Dişli*, Murat Gümüş, Kubra Ünal, Nurşen Sarı, Fatma Arslan \\ Department of Chemistry, Faculty of Science, Gazi University, Ankara, Turkey \\ adisli@gazi.edu.tr
}

\begin{abstract}
A novel series of 2-((-1-substituted phenyl-1 $H$-tetrazol-5-yl)thio)-2,3-dihydro-1 $H$-inden-1-one compounds were designed, synthesized, and evaluated as multi-potent anti-Alzheimer drug candidates. First, treatment of various organic isothiocyanates with sodium azide in the presence of pyridine gave corresponding 1-substituted phenyl-1H-tetrazol-5-thiol compounds. Then, novel 2-((-1-substituted phenyl-1 $H$-tetrazol-5-yl)thio)-2,3-dihydro- $1 H$-inden-1-one compounds were synthesized by treatment of 2,3-dihydro- $1 H$-inden-1-one with the 1-substituted phenyl-1H-tetrazol-5-thiol in the presence of $\mathrm{I}_{2}$. The synthesized compounds were characterized by spectroscopic methods. The inhibitory effects of the synthesized compounds on the acetyl cholinesterase enzyme (AChE) were then tested. An $o$-iodo substituent displayed higher activity compared to the other analogs. The $o$-iodo substituent showed a mixed-type of the AChE with an $I C_{50}$ value of $1.75 \mu \mathrm{M}$. For the studied compunds all $I C_{50}$ values for AChE were in the micromolar range.
\end{abstract}

Key words: Alzheimer's disease; tetrazole; inhibition

\section{НОВИ МУЛТИФУНКЦИОНАЛНИ СРЕДСТВА И НИВНО ИНХИБИТОРНО ДЕЈСТВО ВРЗ АЦЕТИЛ ХОЛИНЕСТЕРАЗНИОТ ЕНЗИМ}

Беше дизајнирана, синтетизирана и евалуирна една нова серија соединенија на 2-((-1супституирани $\quad$ фенил-1H-тетразол-5-ил)тио)-2,3-дихидро- $1 H$-инден-1-он $\quad$ како $\quad$ потенцијални мултипотентни кандидати за лекови против Алцхајмерова болест. Најпрво, третирањето на разни органски изотиоцијанати со натриумазид во присуство на пиридин ги дава соодветните соединенија 1-супституиран фенил- $1 H$-тетразол-5-тиол. Потоа, беа синтетизирани новите соединенија 2-((-1-супституиран фенил- $1 H$-тетразол-5-ил)тио)-2,3-дихидро- $1 H$-инден-1-он $\quad$ со третирање на 2,3-дихидро- $1 H$-инден-1-он со 1 -супститиран фенил- $1 H$-тетразол-5-тиол во присуство на $\mathrm{I}_{2}$. Синтетизираните соединенија беа карактеризирани со спектроскопски методи. Беа тестирани инхибиторните ефекти на синтетизираните соединенија врз ацетил холинестеразниот ензим (AChE). Најголема активност во споредба со сите аналози покажа $o$-јодо супституентот. Овој супституент покажа мешан тип на $\mathrm{AChE}$ со вредност на $I C_{50}$ од $1,75 \mu \mathrm{M}$. За сите испитувани соединенија сите вредности на $I C_{50}$ беа во микромоларен опсег.

Клучни зборови: Алцхајмерова болест; тетразол; инхибиција

\section{INTRODUCTION}

Alzheimer's disease (AD) is a neurodegenerative disease and the main cause of dementia in the elderly (especially people $>65$ years-old). Although the definite causes of $\mathrm{AD}$ remain unknown, low levels of acetylcholine (ACh), the inflamma- tion of neurons, Tau-protein aggregation and $\beta$ amyloid $(\mathrm{A} \beta)$ deposits are thought to play definitive roles in this disease [1]. There are currently two major hypotheses regarding $\mathrm{AD}$, including (1) the cholinergic hypothesis, and (2) the amyloid hypothesis. AD drug therapy is based on the cholinergic hypothesis. The cholinergic hypothesis 
includes the following four acetyl cholinesterase $(\mathrm{AChE})$ inhibitors: tacrine, rivastigmine, galanthamine and donepezil [2, 3]. However, these AChE inhibitors have side effects, including hepatotoxicity, gastrointestinal tract excitement and hallucination. Therefore, the identification of new and better AChE inhibitors remains an important goal.

Some research groups including Badia et al., Roman et al., and Camps et al., have synthesized anticholinesterasic drugs .These drugs show high selectivity and potent inhibitory action on AChE in both in vitro and ex vivo studies $[4,5]$. Coumarin has also been shown to be effective for treating cognitive deficit and delaying the neurodegenerative process (6). N. Guzior et al. have developed a new series of AChE inhibitors that were designed as dual binding site cholinesterase inhibitors able to bind to both the catalytic anionic site (CAS) and the peripheral anionic site (PAS) [6]. Guzior et al. developed a new series of AChE inhibitors that were designed as dual binding site cholinesterase (ChE) inhibitors able to bind to both the catalytic anionic site (CAS) and the peripheral anionic site (PAS) [6].

Some reviews indicate that Donepezil is a new class of ChE inhibitor having N-benzylpiperidine and indanone moiety [7, 3]. Donepezil-like multifunctional agents have been widely employed to improve the performance of $\mathrm{AChE}$ inhibitors.

Tetrazole derivatives, including indanone have attracted interest as excellent candidates to improve the performance of AChE inhibitors. Tetrazole chemistry has steadily developed since the 1980s. Tetrazoles are important heterocylic compounds, known as the nitrogen analogs of the carboxylic acids [8]. Tetrazoles possess various biological activities, such as antibacterial, antituberculosis, antifungal, antiviral, antiallergic, antiulcer, anti-inflammatory and anticonvulsant acvtivities [9, 10]. Furthermore, 1,5-disubstituted tetrazoles, such as cardiazole, are known to have a stimulating effects on the central nervous system [11-13]. The sulfur-containing 5-thiosubstituted tetrazole compounds have been the focus of recent research interest regarding their use in medicinal chemistry, especially for cancer, acquired immune deficiency syndrome (AIDS), hypertension treatments as well as for their HIV (Human Immunodeficiency Virus)-protease inhibitory activity $[14,15]$. The 2,3 dihydroinden-containing skeleton compounds are also important in medicinal chemistry. The 2,3-dihydroinden derivatives are commonly used as antibacterial agents, antiinflammatory agents, cerebral activators and in the treatment of amnesia [9]. In addition, the inden derivative compounds have been used as calcium channel modulators and neuroactive dopamine $\beta$ hydroxylase inhibitors [16-18]. Thus, there is considerable interest in the synthesis and characterization of multifunctional agents involving indanone and tetrazole (Fig. 1). Here we synthesized novel thiotetrazole-containing compounds to provide communication between the nerves, which show inhibition of the AChE. The structures of these compounds were evaluated using Fourier Transform Infrared (FT-IR), Proton Nuclear Magnetic Resonance ( $\left.{ }^{1} \mathrm{H}-\mathrm{NMR}\right)$, Carbon-13 Nuclear Magnetic Resonance $\left({ }^{13} \mathrm{C}-\mathrm{NMR}\right)$ and High Resolution Mass Spectrometry (HR-MS). Finally, we examined the inhibition effect of these compounds against $\mathrm{AChE}$, purified from Electrophorus electricus (electric eel) type V-S.

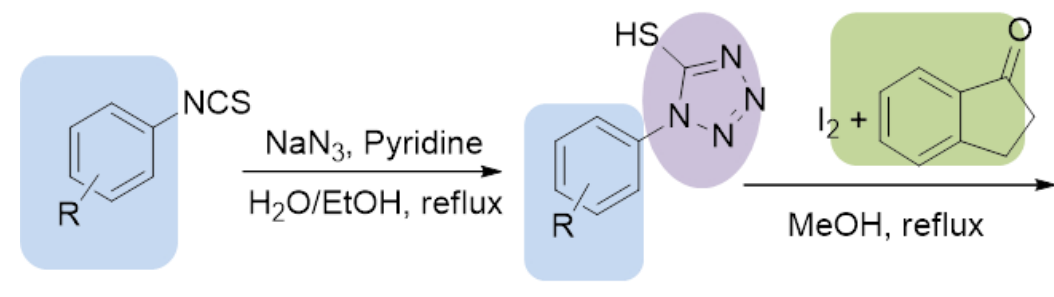

(1-22a)

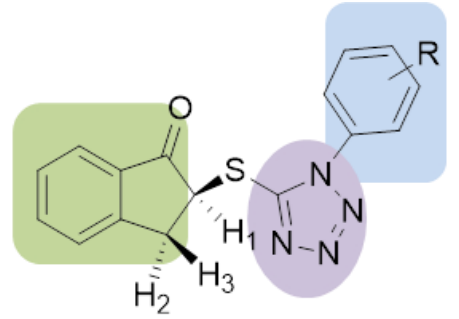

(1-22b)

$\mathrm{R}=-\mathrm{H}, o-[-\mathrm{F}], m-[-\mathrm{F}], p-[-\mathrm{F}], o-[-\mathrm{Cl}], m-[-\mathrm{Cl}], p-[-\mathrm{Cl}], o-[-\mathrm{Br}], m-[-\mathrm{Br}], p-[-\mathrm{Br}], o-[-\mathrm{I}], m-[-\mathrm{I}], p-[-$ $\mathrm{I}], o-\left[-\mathrm{CH}_{3}\right], m-\left[-\mathrm{CH}_{3}\right], p-\left[-\mathrm{CH}_{3}\right], o-\left[-\mathrm{OCH}_{3}\right], m-\left[-\mathrm{OCH}_{3}\right], p-\left[-\mathrm{OCH}_{3}\right], o-\left[-\mathrm{NO}_{2}\right], m-\left[-\mathrm{NO}_{2}\right], p-\left[-\mathrm{NO}_{2}\right]$

Fig. 1. Synthesis rotation of multifunctional agents containing thiotetrazole 


\section{EXPERIMENTAL}

The organic isothiocyanates and other chemicals were obtained from Merck, Fluka Sigma-Aldrich, and Alfa Aesar. All melting points were determined in sealed capillaries and are reported without correction. FT-IR spectra were recorded on a Mattson 1000 spectrometer as $\mathrm{KBr}$ pellets or on a Thermo Nicolet 6700 spectrometer. ${ }^{1}$ H-NMR spectra were recorded on a Varian Gemini 300 (300 MHz) NMR spectrometer in dimethyl sulfoxide (DMSO)- $\mathrm{d}^{6}$ and $\left(\mathrm{CHCl}_{3}\right)-\mathrm{d}^{1}$. ${ }^{13} \mathrm{C}-\mathrm{NMR}$ spectra were recorded on a Varian Gemini $300(75 \mathrm{MHz})$ NMR spectrometer in (DMSO) $-\mathrm{d}^{6}$ and $\left(\mathrm{CHCl}_{3}\right)-\mathrm{d}^{1}$. Mass spectra measurements were recorded on a Thermo Finnigan Trace DSQ. Ultraviolet-visible (UV) spectra were recorded on a Schimadzu UV Spectrophotometer, UV 1800 Model.

\subsection{Preparation of 1-substituted phenyl-1H- tetrazol-5-thiol from organic phenylisothiocyanates (1-22a)}

Sodium azide $\left(\mathrm{NaN}_{3}, 2.5 \mathrm{mmol}\right)$ was dissolved in $10.0 \mathrm{ml}$ of $\mathrm{H}_{2} \mathrm{O}: \mathrm{EtOH}(3: 1)$. Then, pyridine $(3.0 \mathrm{mmol})$ and a substituted phenyl isothiocyanate derivative $(1.0 \mathrm{mmol})$ were added to the solution. The mixture was refluxed for $\sim 16$ $\mathrm{h}$, and the reaction was monitored by Thin Layer Chromatography (TLC). The EtOH of the obtained mixture was removed under vacuum. Ethyl acetate $(10.0 \mathrm{ml})$ was added to the mixture, and the organic layer was extracted with water three times. The aqueous layer was collected and acidified with $3 \mathrm{M}$ $\mathrm{HCl}$ to $\mathrm{pH}$ 1-2. The 1-substituted phenyl-1Htetrazole-5-thiol was precipitated as a white/yellow solid. The solid was filtered, dried, and recrystallized with ethyl acetate and $n$-hexane.

\subsection{Preparation of 2-((1-substituted phenyl-1H- tetrazol-5-yl)thio)-2,3-dihydro-1H-inden-1-one}

$$
(1-22 b)
$$

The 1-substituted phenyl-1H-tetrazole-5thiol $(1.0 \mathrm{mmol})$ was dissolved in $3.0 \mathrm{ml}$ of $\mathrm{MeOH}$. Then, $\mathrm{I}_{2}(1.5 \mathrm{mmol})$ and 2,3-dihydro- $1 H$-inden-1one $(1.5 \mathrm{mmol})$ were added over the solution, and the mixture refluxed for $\sim 18 \mathrm{~h}$. Then, $4.5 \mathrm{ml}$ of $\mathrm{H}_{2} \mathrm{O}$ were added over the mixture and extracted with ethyl acetate $(3 \times 10.0 \mathrm{ml})$. The collected organic layer was extracted with $10 \%$ anhydrous sodium thiosulfate solution $(2 \times 10.0 \mathrm{ml})$ to remove excess $I_{2}$. The organic layer was then dried over anhydrous sodium sulfate, filtered, and the solvent was removed under vacuum. The obtained solid was separated by column chromatography with ethyl acetate/ $n$-hexane (1/3) and recrystallized with ethyl acetate $/ n$-hexane.

\subsection{Inhibition studies of Acetyl Cholinesterase Enzyme (AChE)}

AChE activity measurements were performed at room temperature according to the spectrophotometric assay of Ellman et al. [20]. The principle of the Ellman method, which is a calorimetric procedure, is that the AChE enzyme catalyzes the hydrolysis reaction of Acetylthiocholine iodide (ATCh) (Fig. 2). Thyocholine, the product of this reaction, forms a yellow-colored compound with 5,5'-ditiyobis-(2nitrobenzoic acid) (DTNB), which is an Ellman reactive and plays a role as a coloring agent. AChE enzyme activity was measured by observing the formed yellow compound (5-thio-2-nitrobenzoic acid) spectrophotometrically at a wavelength of $412 \mathrm{~nm}$. ATCh was used as the substrate for all experiments. Stock inhibitor solutions were prepared in DMSO. The solvent concentration was never more than $0.4 \%(\mathrm{v} / \mathrm{v})$ in the reaction mixture. The reaction mixtures for the determination of the $I C_{50}$ values were composed of inhibitor $\left(1.0 \times 10^{-4}\right.$ $\mathrm{M}$ to $\left.1.0 \times 10^{-8} \mathrm{M}\right)$, ATCh $\left(1.0 \times 10^{-4} \mathrm{M}\right), 5,5^{\prime}-$ dithiobis(2-nitrobenzoic acid) (DTNB) $\left(0.67 \times 10^{-4}\right.$ $\mathrm{M}), \operatorname{AChE}(5.0 \mathrm{unit} / \mathrm{ml})$, and $0.1 \mathrm{M}$ phosphate buffer $(\mathrm{pH}=8.0)$. After $30 \mathrm{~min}$ incubation, the absorbance of the mixture was monitored using a spectrophotometer at $412 \mathrm{~nm}$. Control experiments were performed in the presence of DMSO. To detect the inhibition type, Lineweaver-Burke graphics were plotted using absorbance values that were obtained in the presence $\left(1.0 \times 10^{-5}, 5.0 \times 10^{-6}\right.$, and $\left.1.0 \times 10^{-7} \mathrm{M}\right)$ and absence of inhibitor. ATCh concentrations used were $3.010^{-3}, 6.0 \times 10^{-3}$, $3.0 \times 10^{-2}$, and $6.0 \times 10^{-2} \mathrm{M}$. The type of inhibition was determined from the $K_{\mathrm{M}}$ and $V_{\max }$ values found in the Lineweaver-Burke plot obtained for the indicated inhibitor concentrations. Inhibition types were determined in the absence and presence of inhibitor using $3.0 \times 10^{-3}$ to $6.0 \times 10^{-2} \mathrm{M}$ ATCh from the Lineweaver-Burke plots. Each determination was repeated three times, and the mean values obtained, $I C_{50}$ and $K_{\mathrm{i}}$ values, were calculated using GraphPad Prism 6 (GraphPad Software). To allow comparison of our results with the literature, Donepezil $\mathrm{HCl}$ was used as the reference compound. The $I C_{50}, K_{\mathrm{i}}$ constants, and the inhibition 
type of the synthesized compounds and Donepezil $\mathrm{HCl}$ are given in Table 1.

\section{RESULTS AND DISCUSSION}

\subsection{Chemistry}

First, we synthesized 1-substituted phenyl$1 H$-tetrazol-5-thiol by reaction of substituted phenylisothiocyanate with sodium azide in water/ethanol in the presence of pyridine (Fig. 1, 122a) and compared the structures of the synthesized compounds against the literature (melting point and FT-IR) [19-23]. We found that the synthesized compounds were consistent with the literature. We then synthesized novel 2-((1-substituted phenyl-1 $H$-tetrazol-5-yl)thio)-2,3-dihydro- $1 H$-inden1 -one compounds by reaction of 1-substituted phenyl-1H-tetrazol-5-thiol with 2,3-dihydro- $1 \mathrm{H}$-inden1-one in the presence of $I_{2}$ in methanol (Fig. 1, 122b). All of the synthesized compounds were characterized by IR, ${ }^{1} \mathrm{H}-\mathrm{NMR},{ }^{13} \mathrm{C}-\mathrm{NMR}$ spectra, and mass spectrometry. In the IR spectrum, the characteristic $\mathrm{C}=\mathrm{O}$ absorption band of the $1 \mathrm{H}$-inden-1one was observed between 1713 and $1728 \mathrm{~cm}^{-1}$, and the $\mathrm{N}=\mathrm{N}$ characteristic absorption band was observed between 1498 and $1528 \mathrm{~cm}^{-1}$. The ${ }^{1} \mathrm{H}$ NMR and ${ }^{13} \mathrm{C}-\mathrm{NMR}$ spectra of the compounds (Fig. 1, 1-22b) are also in agreement with the proposed structures.

\subsection{In vitro inhibition of $A C h E$}

The inhibitory effects of the synthesized compounds on AChE were evaluated using the Ellman method (Fig. 2 and Fig. 3) [20-25], with Donepezil $\mathrm{HCl}$ as the positive control. We examined the inhibition effect of the synthesized compounds against $\mathrm{AChE}$, purified from Electrophorus electricus (electric eel) type V-S, with an activity of $100 \mathrm{unit} / \mathrm{mL}$. The $\mathrm{IC}_{50}$ values for $\mathrm{AChE}$ inhibition and the selectivity for AChE are summarized in Table 1. We found that all of the synthesized compounds exhibit inhibitory activities.

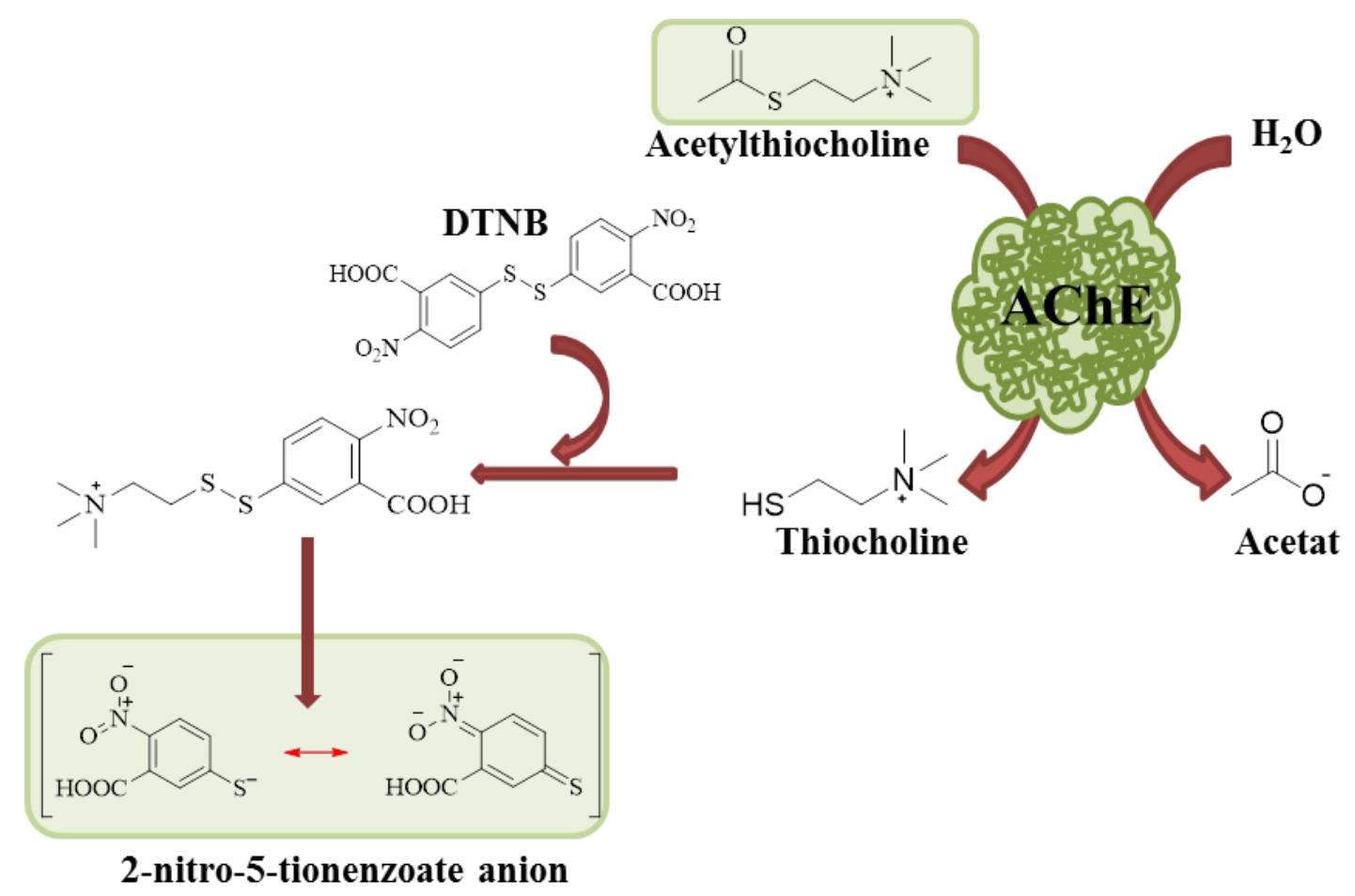

Fig. 2. Hydrolysis mechanism of acetylcholine (ACh) catalyzed by acetylcholinesterase (AChE); DTNB: 5,5'-dithiobis(2-nitrobenzoic acid)

Michaelis-Menten and Lineweaver-Burke graphics were plotted for all compounds (Fig. 3). When Figure 3 is examined, it can be seen that $K_{\mathrm{m}}$ and $V_{\max }$ values decrease for each compound when compared to plots without inhibitor. This type of inhibition is called mixed inhibition. Because of this, the inhibition types of the compounds were detected as mixed inhibition. $I C_{50}$ and $K_{\mathrm{i}}$ values were calculated using GraphPad Prism 6 (GraphPad Software). 
Figure 3

Michaelis-Menten and Lineweaver-Burke plots for $1 \mathrm{~b}$
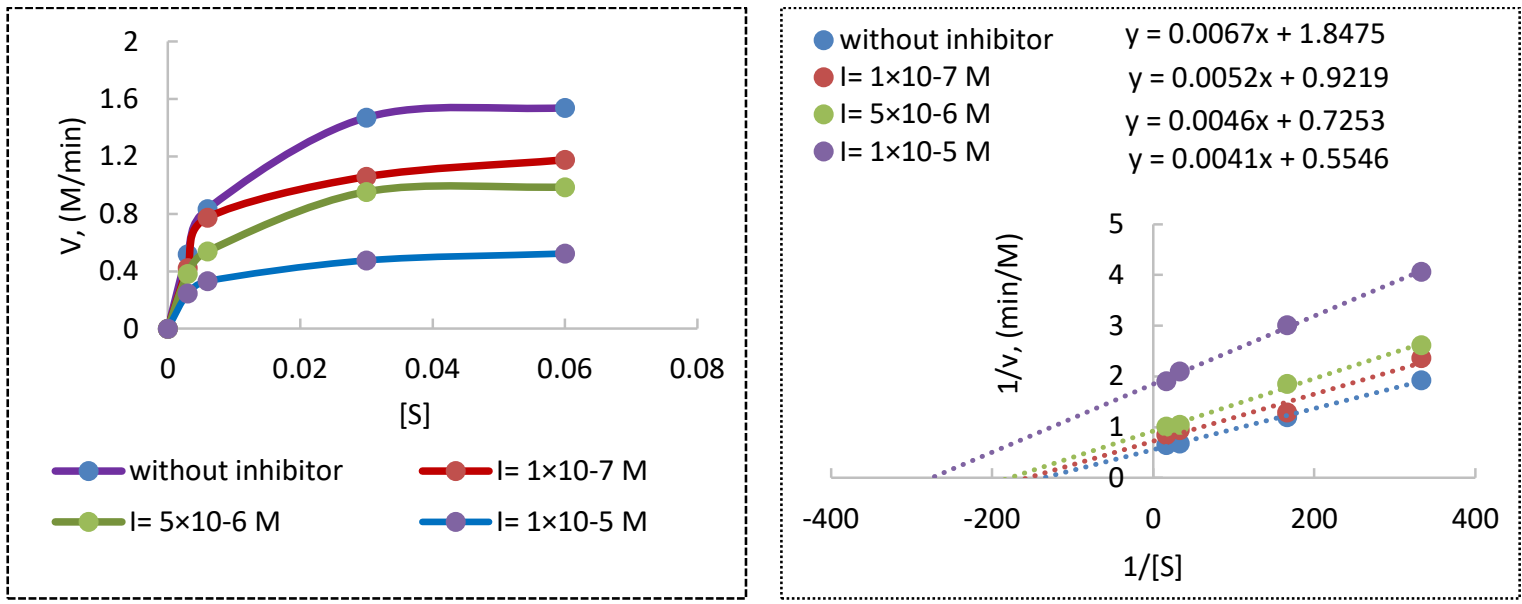

Michaelis-Menten and Lineweaver-Burke plots for $2 \mathrm{~b}$
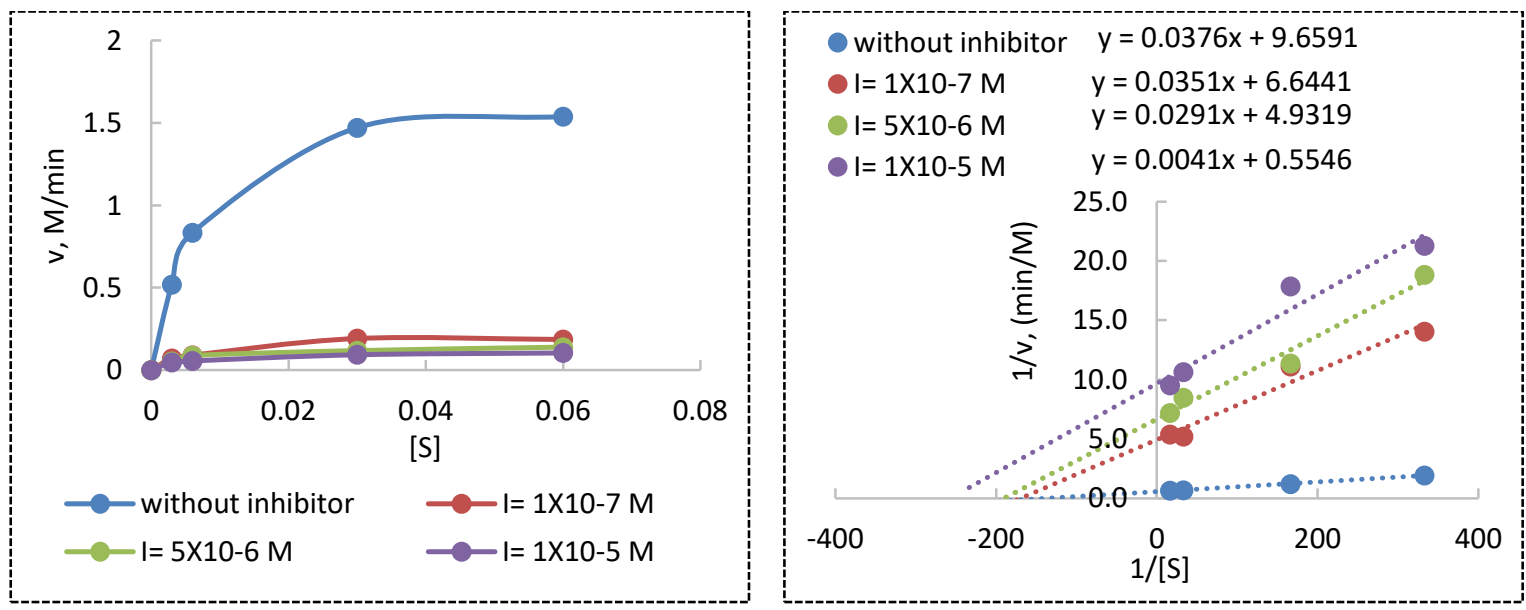

Michaelis-Menten and Lineweaver-Burke plots for 3b
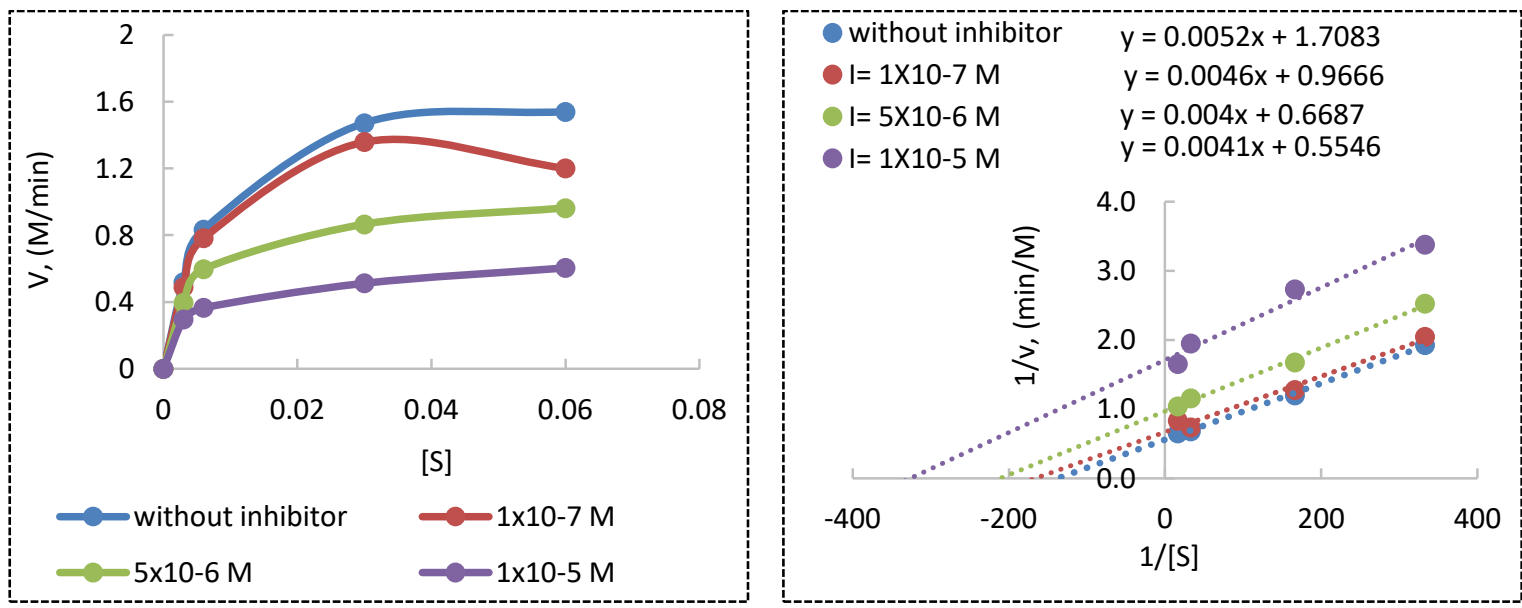
Michaelis-Menten and Lineweaver-Burke plots for $4 \mathrm{~b}$
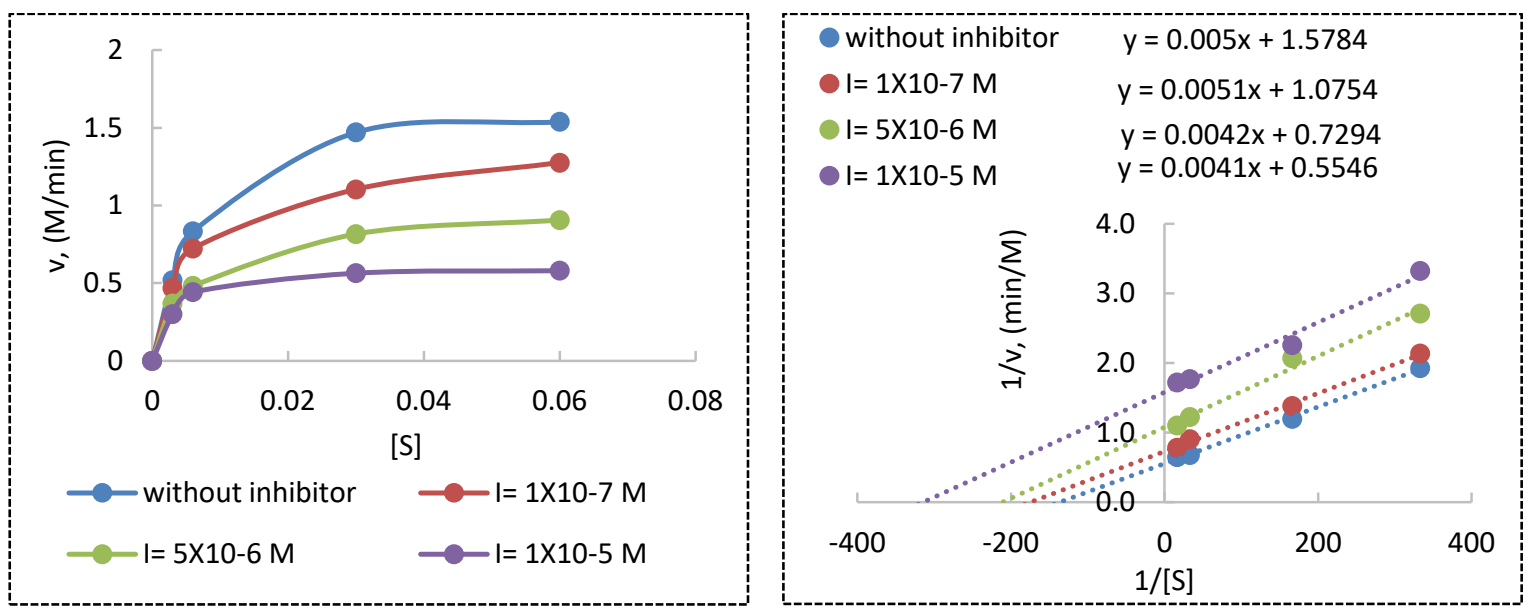

Michaelis-Menten and Lineweaver-Burke plots for $5 \mathrm{~b}$
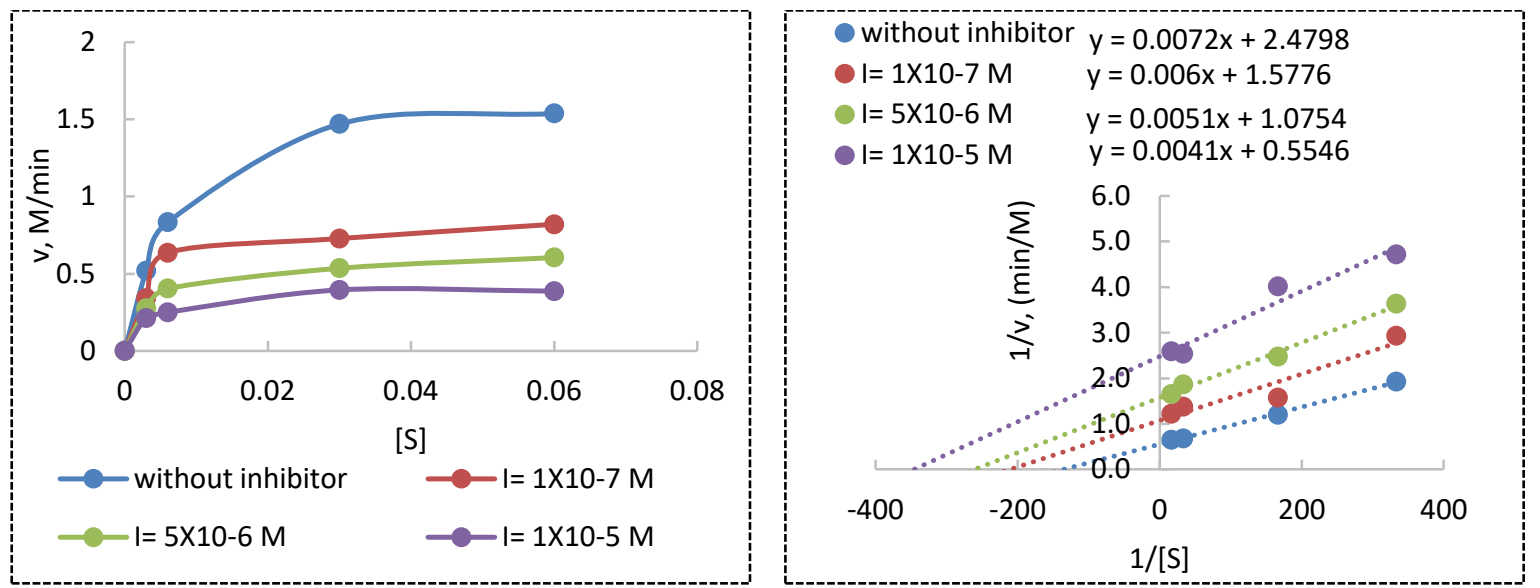

Michaelis-Menten and Lineweaver-Burke plots for $7 \mathrm{~b}$
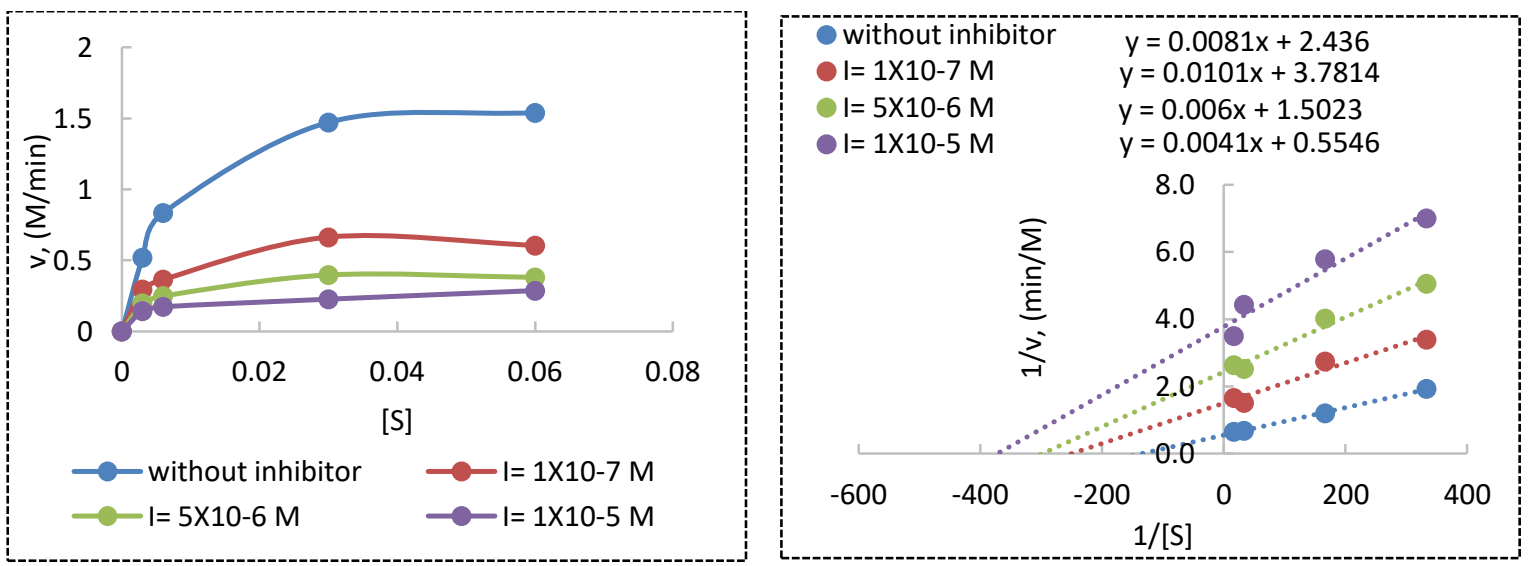
Michaelis-Menten and Lineweaver-Burke plots for $8 \mathrm{~b}$
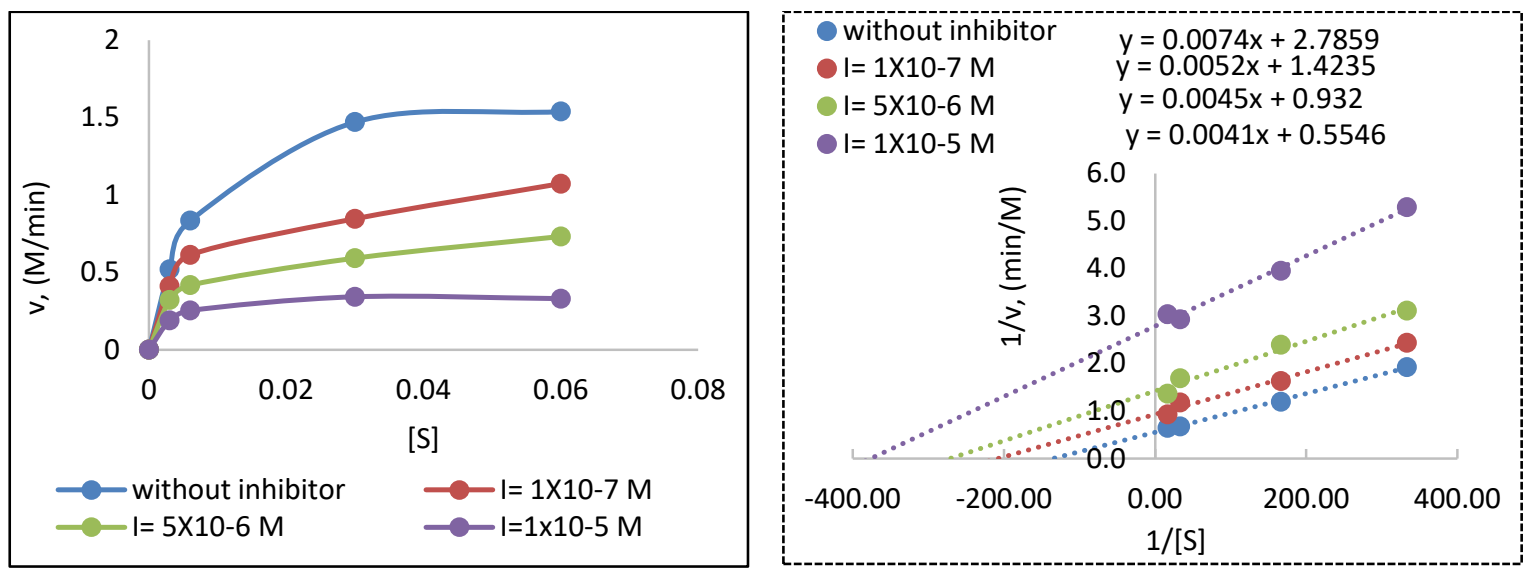

Michaelis-Menten and Lineweaver-Burke plots for $9 \mathrm{~b}$
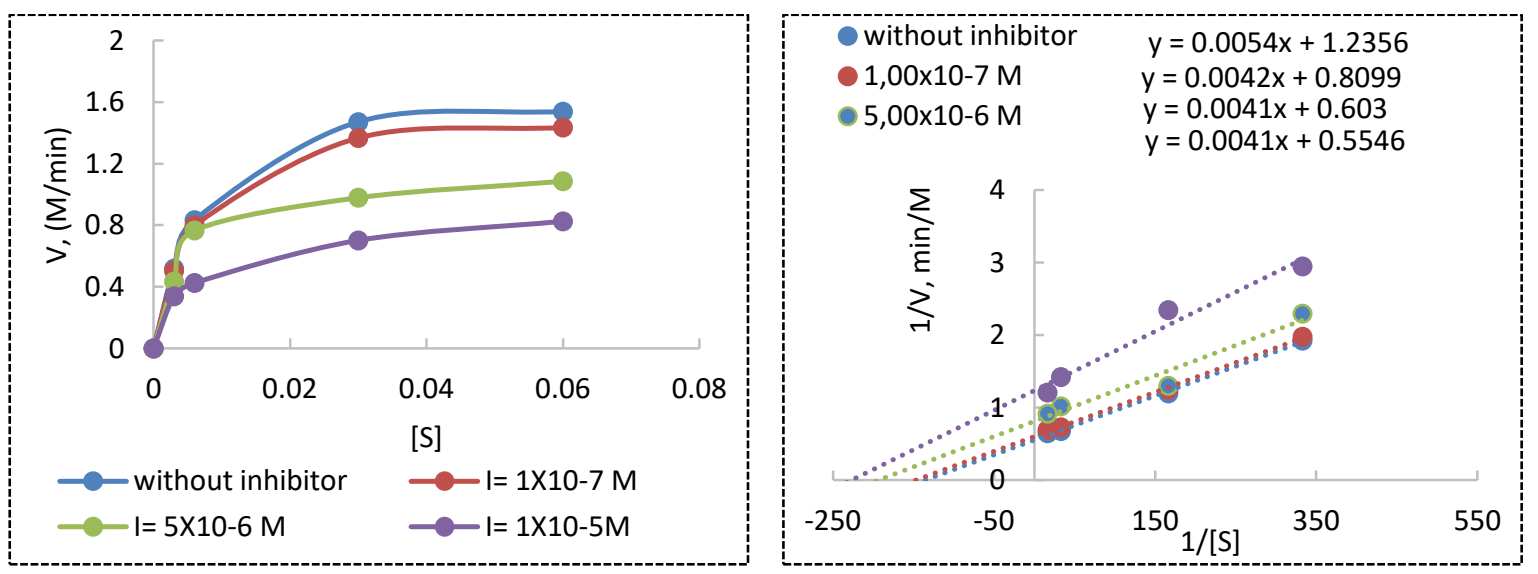

Michaelis-Menten and Lineweaver-Burke plots for 10b
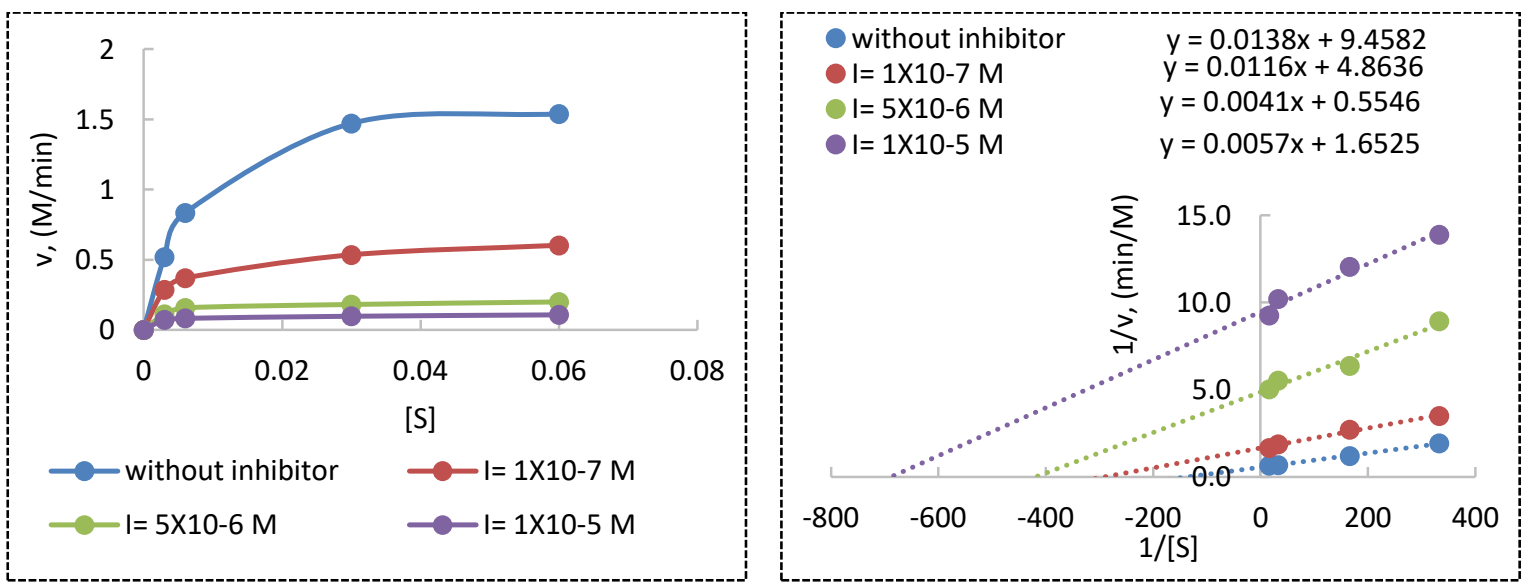
Michaelis-Menten and Lineweaver-Burke plots for $11 \mathrm{~b}$
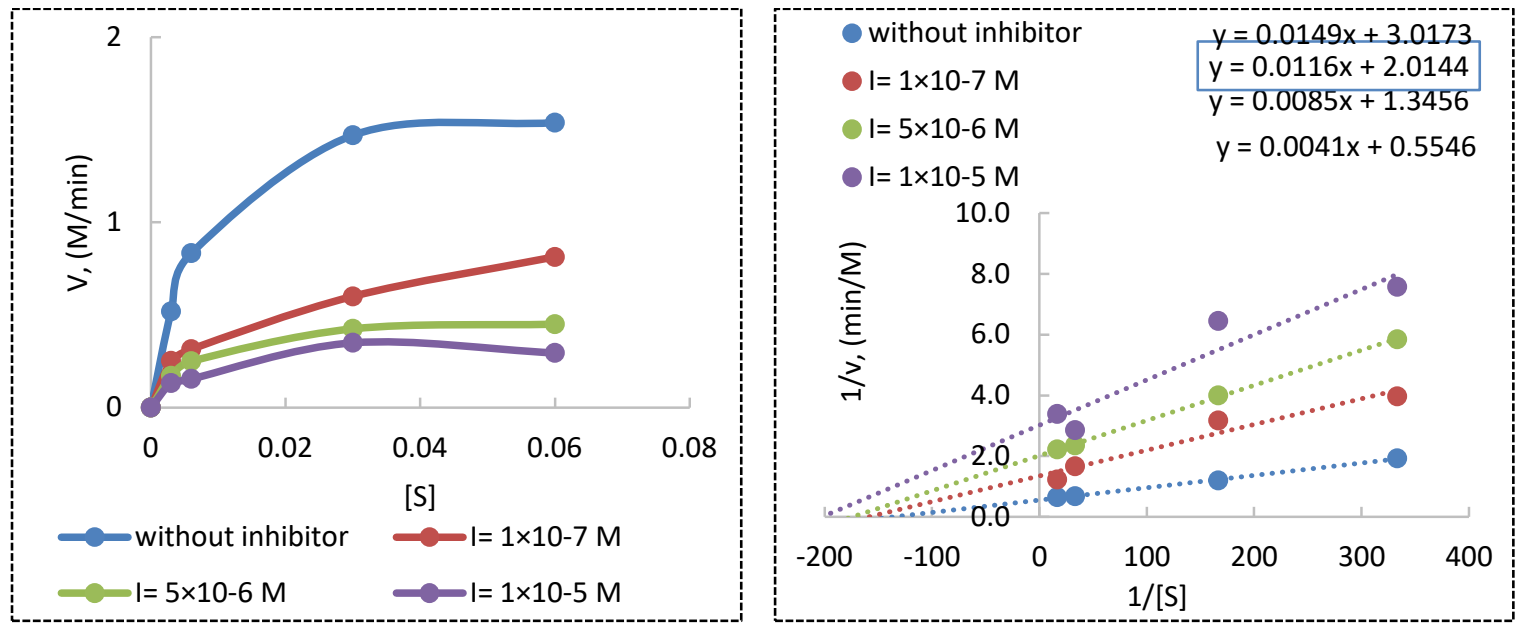

Michaelis-Menten and Lineweaver-Burke plots for $12 \mathrm{~b}$
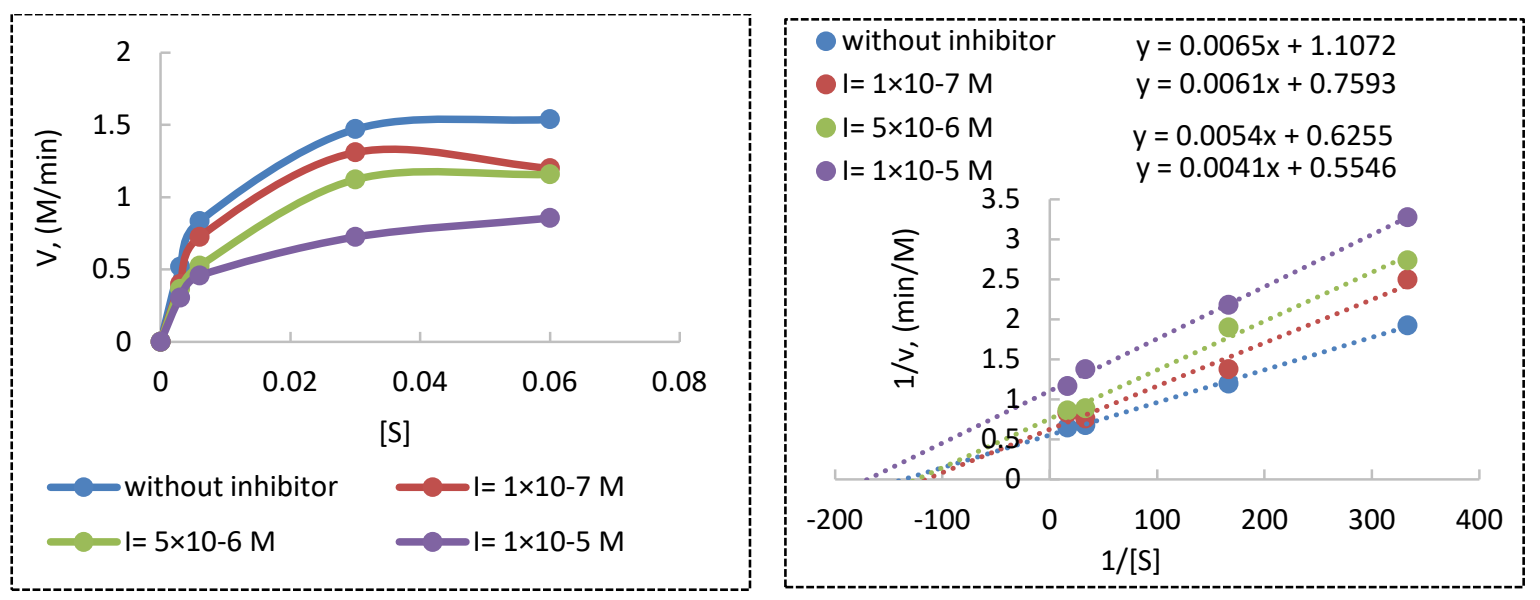

Michaelis-Menten and Lineweaver-Burke plots for $13 \mathrm{~b}$
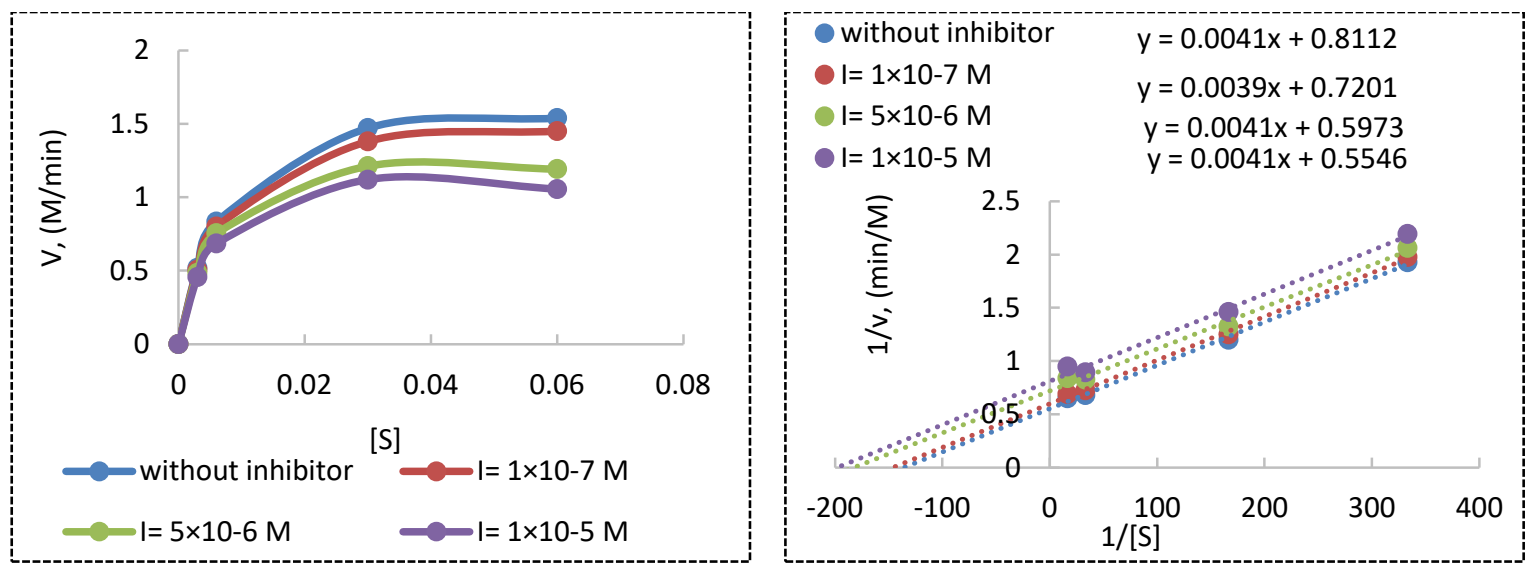
Michaelis-Menten and Lineweaver-Burke plots for 14b
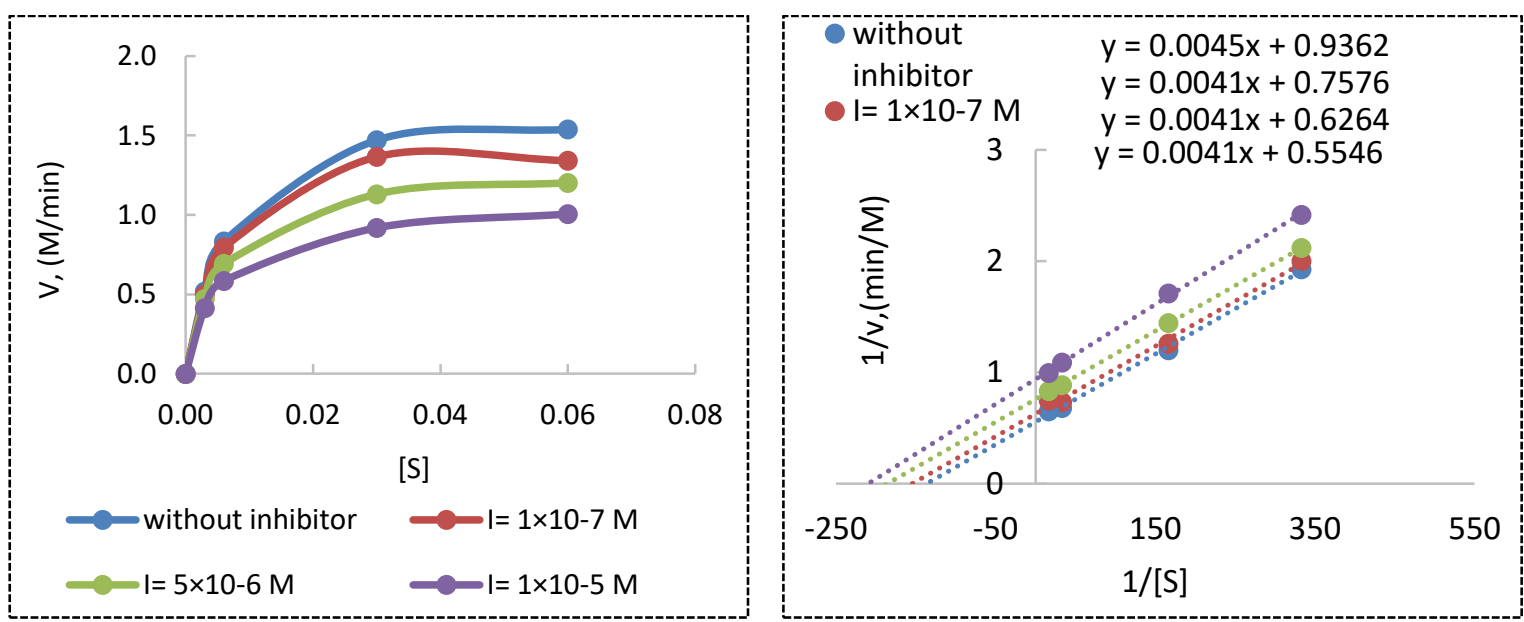

Michaelis-Menten and Lineweaver-Burke plots for $15 \mathrm{~b}$
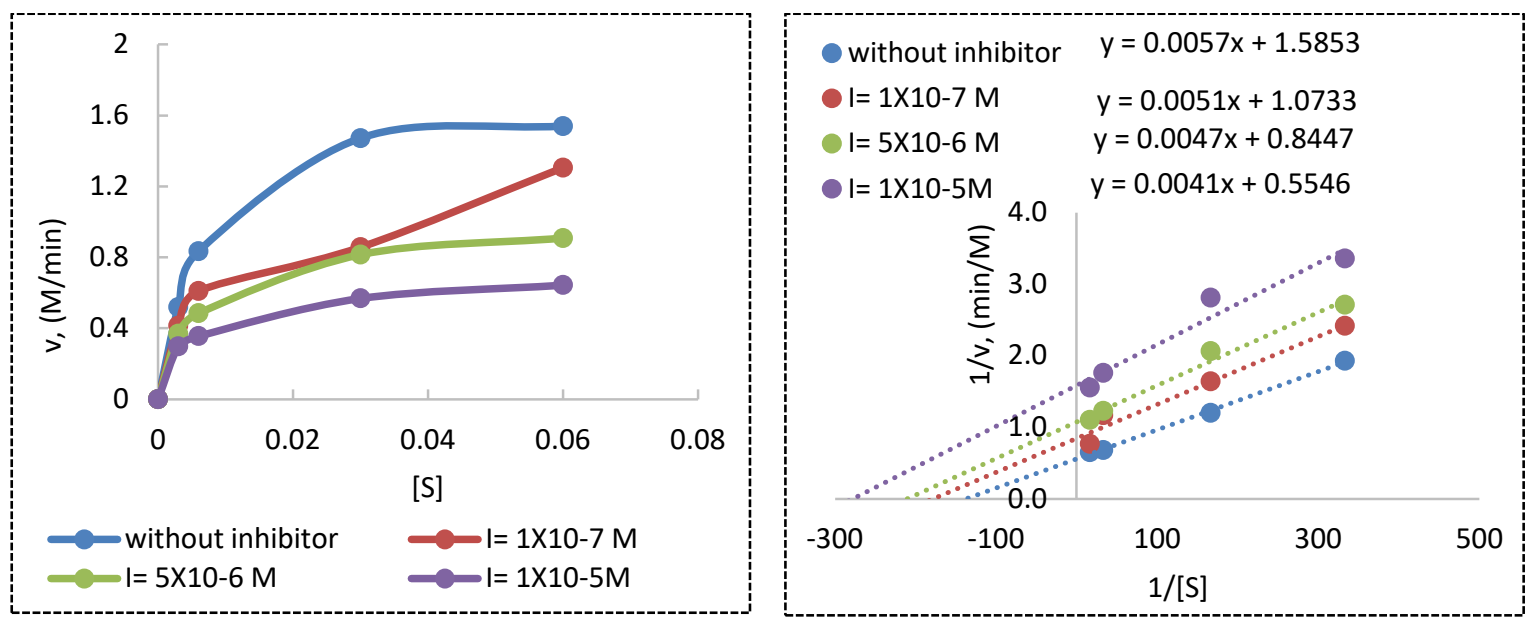

Michaelis-Menten and Lineweaver-Burke plots for $16 \mathrm{~b}$

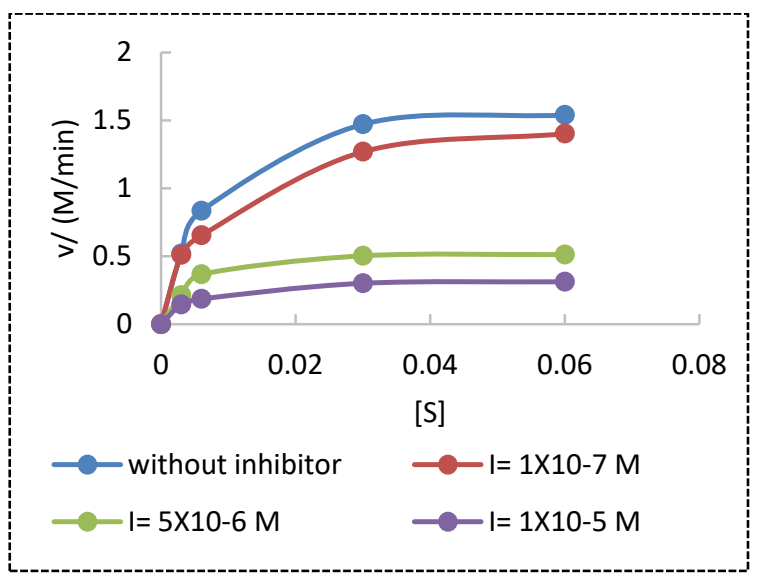

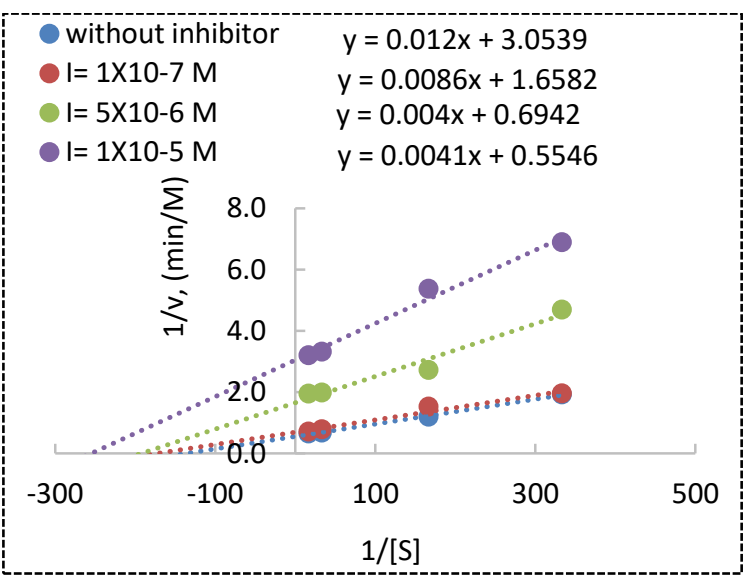


Michaelis-Menten and Lineweaver-Burke plots for $17 \mathrm{~b}$
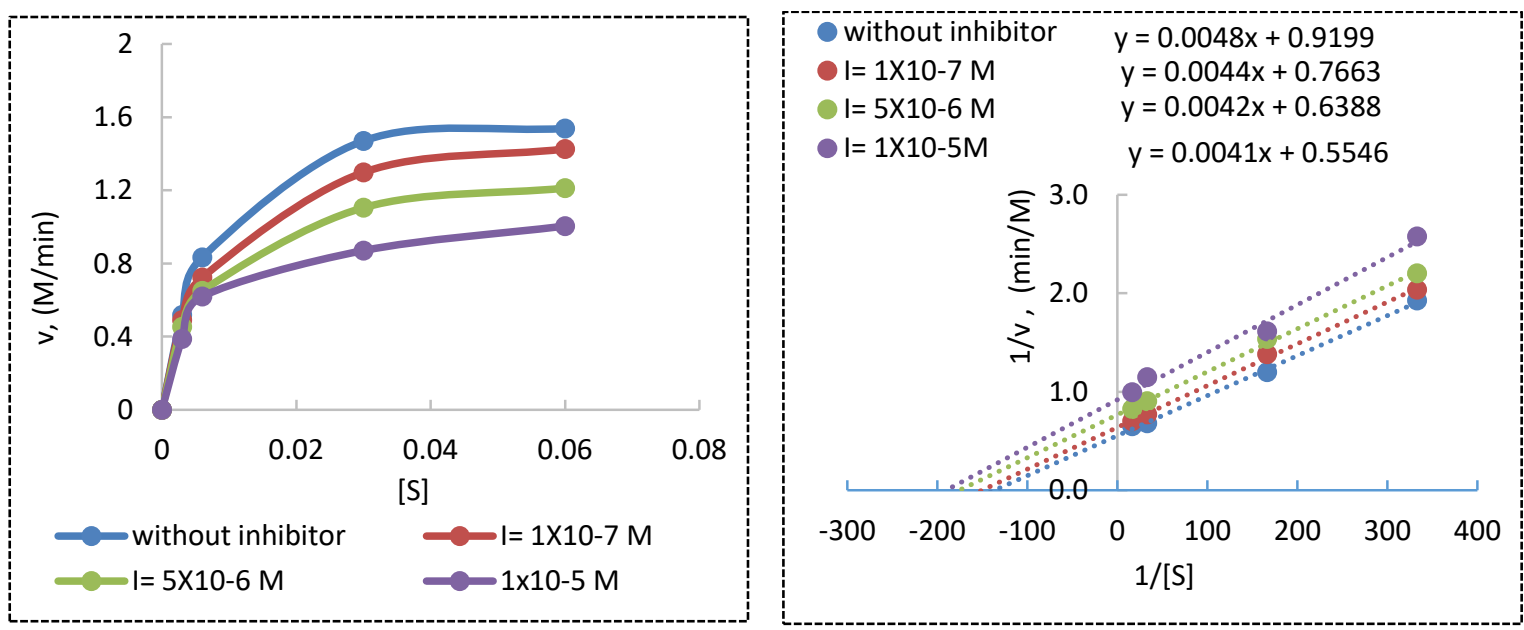

Michaelis-Menten and Lineweaver-Burke plots for $18 \mathrm{~b}$
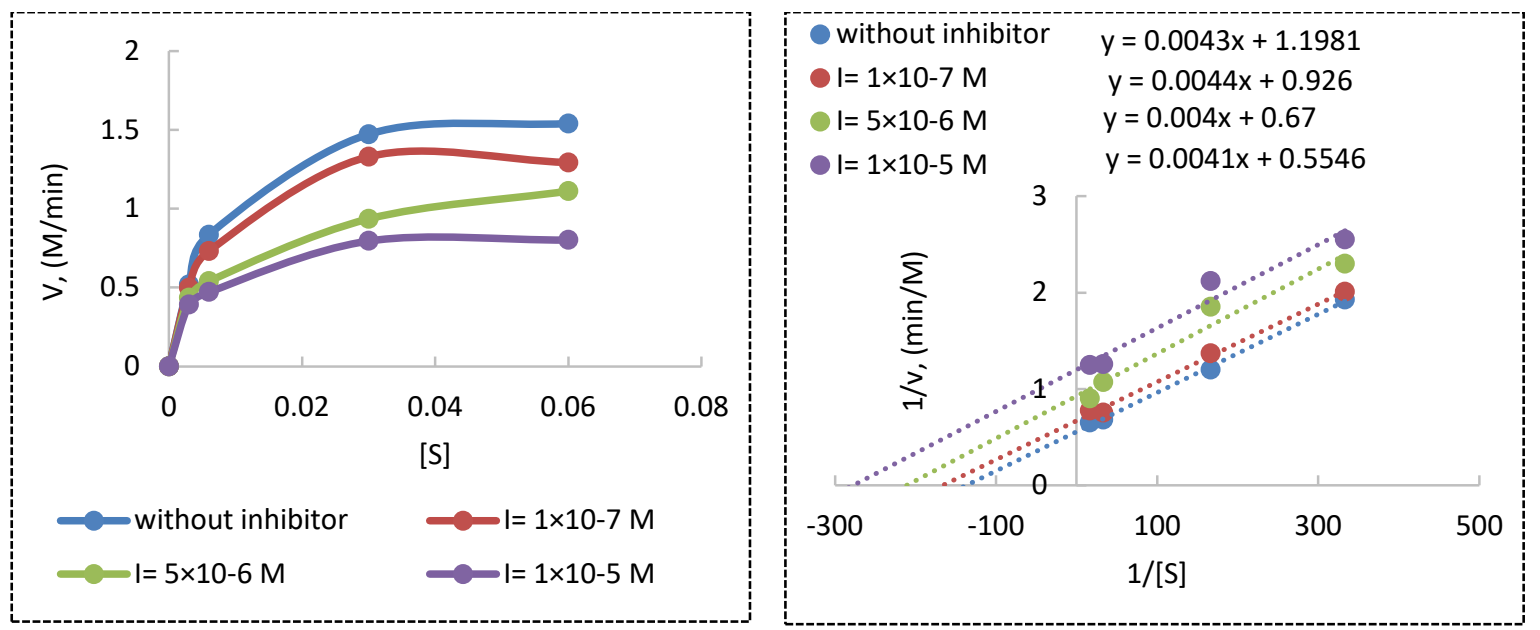

Michaelis-Menten and Lineweaver-Burke plots for $19 \mathrm{~b}$
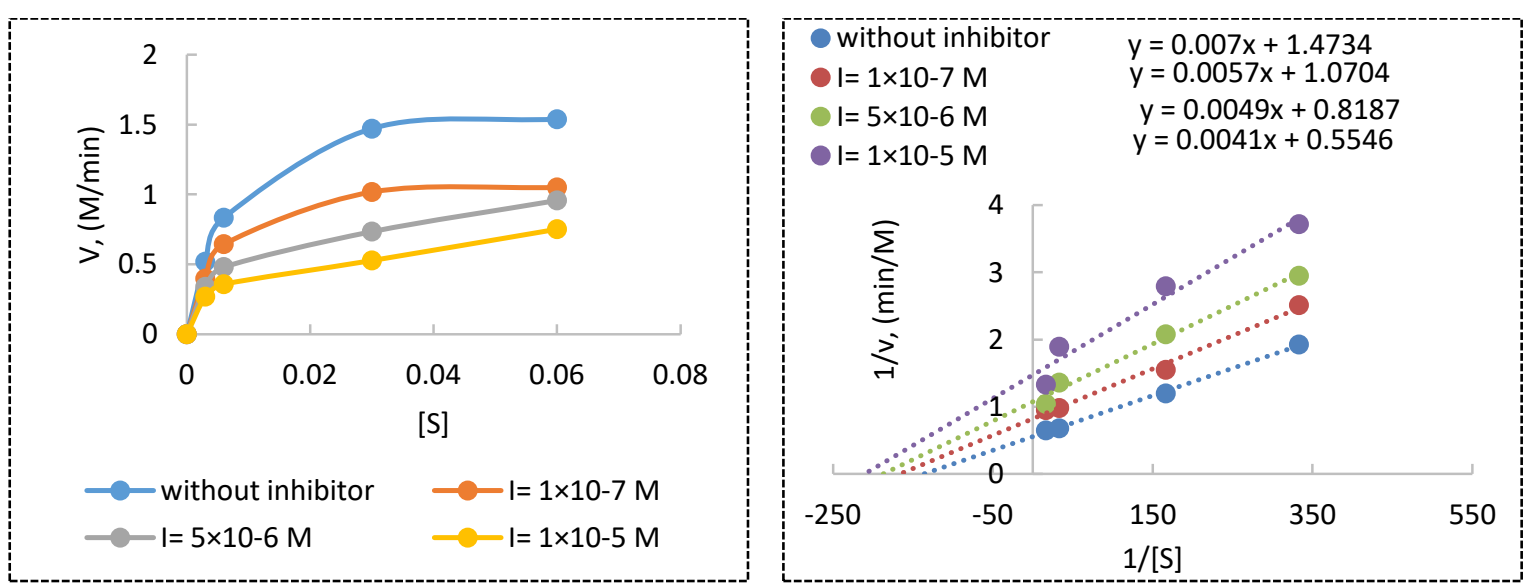
Michaelis-Menten and Lineweaver-Burke plots for 20b
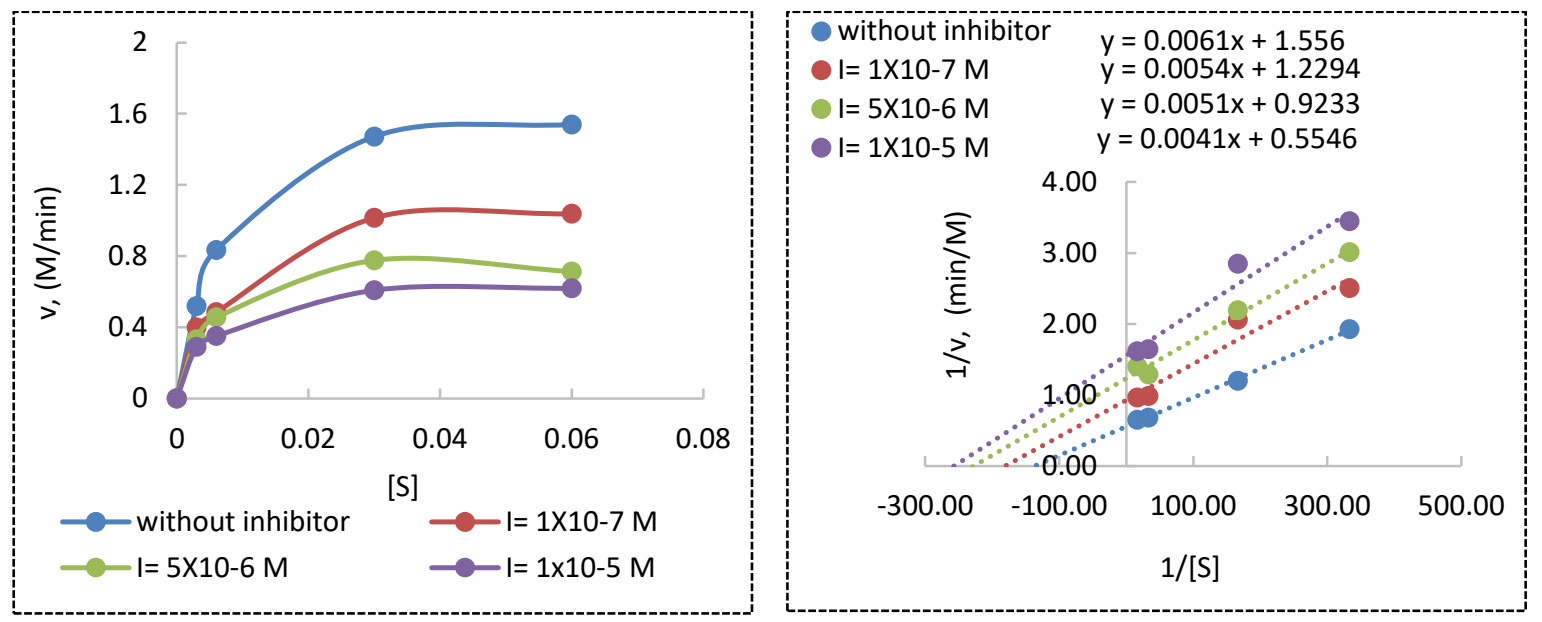

Michaelis-Menten and Lineweaver-Burke plots for 21b
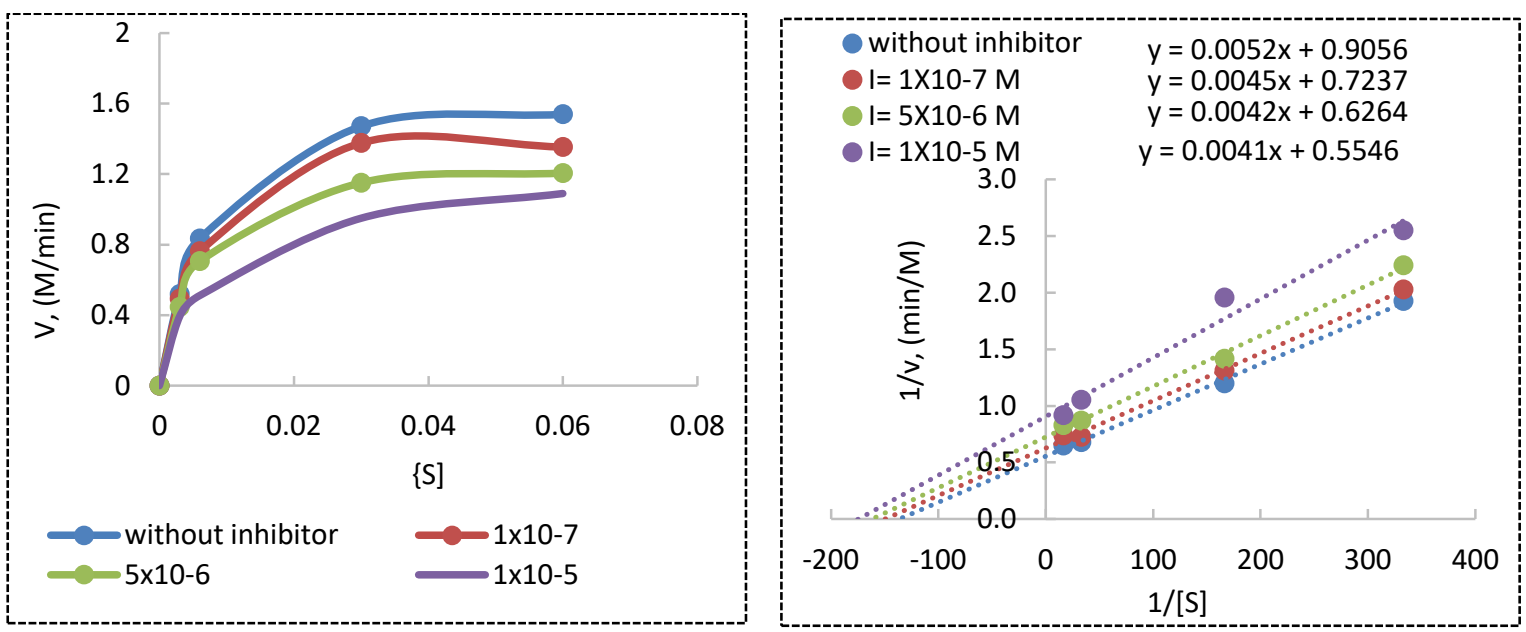

Michaelis-Menten and Lineweaver-Burke plots for 22b

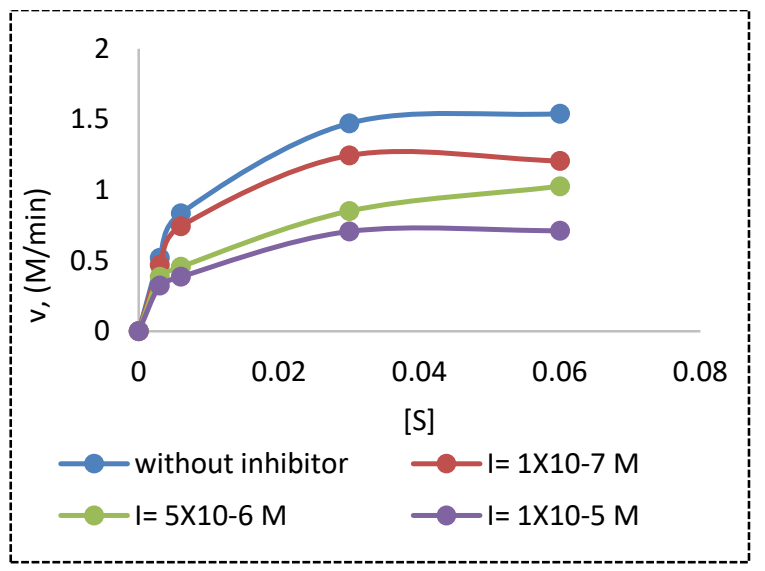

\begin{tabular}{|c|c|c|c|}
\hline \multirow{4}{*}{\multicolumn{2}{|c|}{$\begin{array}{l}\text { without inhibitor } \\
\text { I }=1 \times 10-7 \mathrm{M} \\
\mathrm{I}=1 \times 10-6 \mathrm{M} \\
\mathrm{I}=10 \mathrm{M}\end{array}$}} & \multirow{4}{*}{$\begin{array}{l}y=0.007 x+1.4734 \\
y=0.0057 x+1.0704 \\
y=0.0049 x+0.8187 \\
y=0.0041 x+0.5546\end{array}$} & \\
\hline & & & \\
\hline & & & \\
\hline & & & \\
\hline \multirow{3}{*}{ 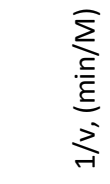 } & 4 & 0 & \\
\hline & 3 &.. $.0^{\circ} .0^{\circ}$ & \\
\hline & & •๑ & \\
\hline \multirow[t]{2}{*}{-250} & \multirow{2}{*}{-50} & 350 & \multirow{2}{*}{550} \\
\hline & & $1 /[\mathrm{S}]$ & \\
\hline
\end{tabular}


Michaelis-Menten and Lineweaver-Burke plots for donepezil
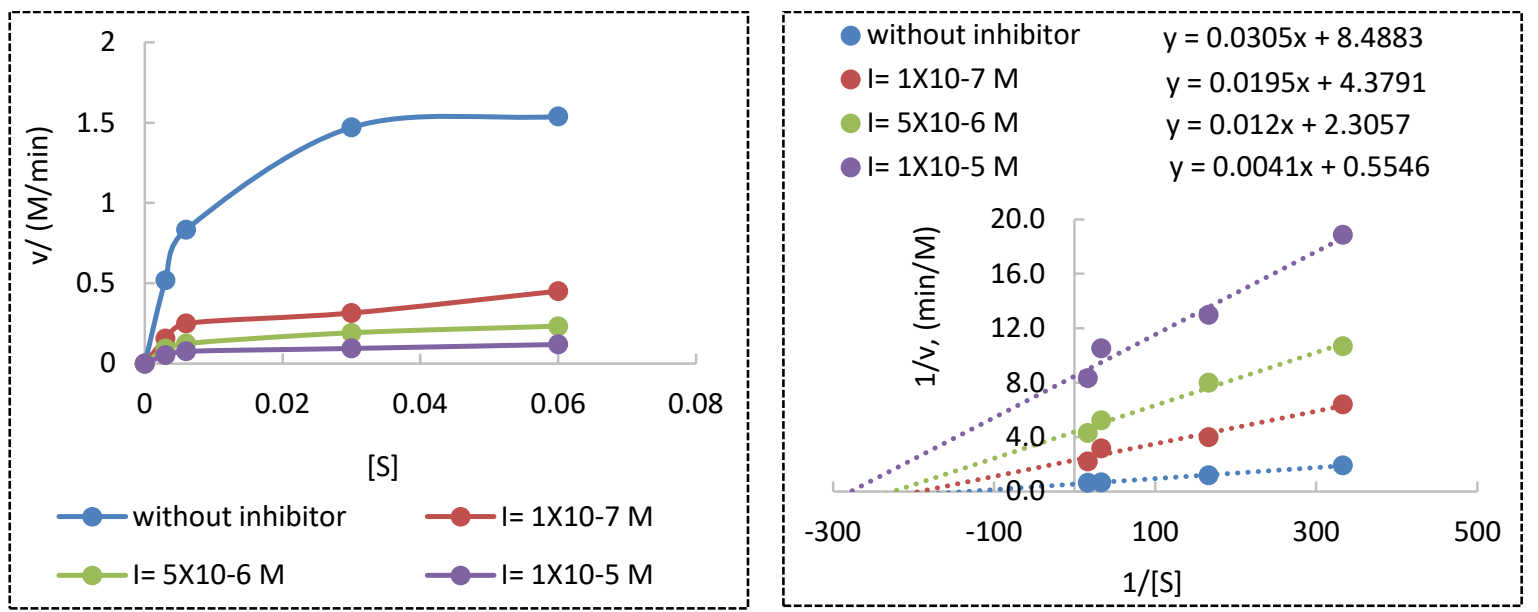

Fig. 3. Michaelis-Menten and Lineweaver-Burk plots for all compounds and Donepezil (except compound 6)

The compounds that involved electronwithdrawing and electron-donating groups exhibited higher inhibitory activities against AChE than the precursor compound $\mathbf{1 b}$. Among the series of 22 compounds, $11 \mathbf{b}\left(I C_{50}=1.75 \mu \mathrm{M}\right)$ was the most active. Compound $9 \mathrm{~b}\left(I C_{50}=1.84 \mu \mathrm{M}\right)$ was the second most active compound of the series (Fig. 4). Compound $13 \mathrm{~b}\left(I C_{50}=7.56 \mu \mathrm{M}\right)$, which is an iodine substituent, showed less activity compared to $\mathbf{2 2 b}$.<smiles>C[C@@]1(Sc2nnnn2-c2ccccc2I)Cc2ccccc2C1=O</smiles><smiles>[CH][C@@]1(c2nnnn2-c2cccc(Br)c2)Cc2ccccc2C1=O</smiles>

Fig. 4. Structure of compounds with the highest inhibition (11b, 9b)

According to structure-activity relationships (SAR) studies [26], hydrophobic binding is important for inhibitors targeting the amino acid residues found in the structure of AChE (Trp 83, Gly 149, Tyr 162, Glu 237, and His 480). The hydrophobic effect plays an important role in the formation of hydrogen bonds between AChE and its inhibitors [27-29]. We know that halogen substituents (especially $-\mathrm{Br}$ and $-\mathrm{I}$ ) increase the lipophilicity (or hydrophobic effect) of the molecules due to their London dispersion forces. Iodine and bromine atoms exert a greater hydrophobic effect than the studied halogens $(-\mathrm{F}$ and $-\mathrm{Cl})$. Thus, the hydrophobic effect may account for the inhibitory activities of compounds $\mathbf{1 1 b}$ and $\mathbf{9 b}$ against AChE. The inhibitory activities for the compounds with $-\mathrm{Br},-$ $\mathrm{F}$, and $-\mathrm{CH}_{3}$ substituents can be ranked as $o->p$ $>m-$. The lowest and highest $I C_{50}$ values were observed for compounds $\mathbf{1 1 b}$ and $\mathbf{1 3 b}$, respectively.

\subsubsection{Electron-withdrawing groups}

The $I C_{50}$ values of the compounds involving $-\mathrm{F}$ and $-\mathrm{Br}$ increase as follows: $o-<p-<m-$. Despite that, values of structures involving $-\mathrm{I}$ and $-\mathrm{NO}_{2}$ increase as follows: $p-<o-<m-$. Due to the insolubility of $\mathbf{6 b}$, a comparison was made between $\mathbf{5 b}$ and $\mathbf{7 b}$. Compound $\mathbf{5 b}$ exhibited higher inhibitory activities against AChE than $\mathbf{7 b}$. Among the halogen groups having a $p$ - position, the inhibition increased with increasing electronegativity.

\subsubsection{Electron donating groups}

The inhibition effect of the compounds with a methyl substituent increases as follows: $o-<p-$ $<m-$. The $I C_{50}$ values of compounds involving $-\mathrm{OCH}_{3}$ increased as follows: $m-<p-<o-$ (Table $1)$. The inhibitory activity against $\mathrm{AChE}$ for $m_{-}$ 
$\mathrm{OCH}_{3}$ was higher than that of the $m-\mathrm{CH}_{3}$ contain- ing compound. Table 1

$$
I C_{50}, K_{i} \text { constants and the inhibition type of synthesized compounds and donepezil.HCl }
$$

\begin{tabular}{|c|c|c|c|c|}
\hline Compounds & $\mathbf{R}$ & Inhibition Type & $\begin{array}{l}I C_{50} \\
{\left[\times 10^{-6} \mathrm{M}\right]}\end{array}$ & $\boldsymbol{K}_{i}$ \\
\hline $1 b$ & $-\mathrm{H}$ & Mixed & 8.28 & 24.11 \\
\hline $2 b$ & $o-[-\mathrm{F}]$ & Mixed & 4.04 & 0.65 \\
\hline $3 b$ & $m-[-\mathrm{F}]$ & Mixed & 2.63 & 24.25 \\
\hline $4 b$ & $p-[-\mathrm{F}]$ & Mixed & 3.04 & 14.22 \\
\hline $5 b$ & $o-[-\mathrm{Cl}]$ & Mixed & 2.79 & 14.30 \\
\hline$* 6 b$ & $m-[-\mathrm{Cl}]$ & - & - & - \\
\hline $7 b$ & $p-[-\mathrm{Cl}]$ & Mixed & 3.89 & 3.80 \\
\hline $8 b$ & $o-[-\mathrm{Br}]$ & Mixed & 5.23 & 9.69 \\
\hline $9 b$ & $m-[-\mathrm{Br}]$ & Mixed & 1.84 & 34.65 \\
\hline $10 \mathrm{~b}$ & $p-[-\mathrm{Br}]$ & Mixed & 4.07 & 3.49 \\
\hline $11 b$ & $o-[-\mathrm{I}]$ & Mixed & 1.75 & 51.70 \\
\hline $12 b$ & $m-[-\mathrm{I}]$ & Mixed & 3.58 & 73.80 \\
\hline $13 b$ & $p-[-\mathrm{I}]$ & Mixed & 10.96 & 132.90 \\
\hline $14 \mathrm{~b}$ & $o-\left[-\mathrm{NO}_{2}\right]$ & Mixed & 8.10 & 12.87 \\
\hline $15 b$ & $m-\left[-\mathrm{NO}_{2}\right]$ & Mixed & 2.86 & 15.83 \\
\hline $16 \mathrm{~b}$ & $p-\left[-\mathrm{NO}_{2}\right]$ & Mixed & 6.67 & 6.14 \\
\hline $17 b$ & $o-\left[-\mathrm{OCH}_{3}\right]$ & Mixed & 2.21 & 108.70 \\
\hline $18 \mathrm{~b}$ & $m-\left[-\mathrm{OCH}_{3}\right]$ & Mixed & 7.37 & 52.87 \\
\hline $19 b$ & $p-\left[-\mathrm{OCH}_{3}\right]$ & Mixed & 3.41 & 75.81 \\
\hline $20 \mathrm{~b}$ & $o-\left[-\mathrm{CH}_{3}\right]$ & Mixed & 7.56 & 13.35 \\
\hline $21 b$ & $m-\left[-\mathrm{CH}_{3}\right]$ & Mixed & 2.34 & 46.53 \\
\hline $22 b$ & $p-\left[-\mathrm{CH}_{3}\right]$ & Mixed & 3.72 & 19.73 \\
\hline Donepezil.HCl & & Mixed & $7.78 \times 10^{-3}$ & 151.92 \\
\hline
\end{tabular}

*: insoluble

\section{CONCLUSION}

Here, we report the synthesis and AChE inhibitory activity of tetrazole derivatives. We synthesized 21 novel compounds (2b-22b), all of which have an inhibitory effect on the AChE enzyme. The structures of these compounds were elucidated using spectroscopic methods. Compound 11b had the highest inhibitory effect (lowest $I C_{50}$ value) and compound $13 \mathrm{~b}$ had the lowest inhibition effect (highest $I C_{50}$ value). The inhibitory effect is improved in substituted phenyl compounds (13b) in which the phenyl is connected to the tetrazole ring. For the halogen-containing compounds, the inhibitory effect, excluding $\mathbf{1 1 b}$ and $\mathbf{9 b}$, was increased by increasing the electronegativity of the halogen. Furthermore, the inhibitory effect increased with the presence of electronwithdrawing groups (halogen and nitro groups) at the $m$ - position, while the inhibitory effect for electron-donating groups increased at the $o-$ position and was observed to not have a correlation in the $m-$ and $p-$ positions for electron-donating groups.

Acknowledgments: The authors gratefully acknowledge the financial support from the Scientific and Technical Research Council of Turkey (TUBITAK, Project No. $114 Z 622$ and Gazi University Scientific Research Projects, Project No. 05/2013-03).

\section{REFERENCES}

[1] P. Kasa, H. Papp, P. J. R. Kasa, I. Torok, Donepezil dose-dependently inhibits acetylcholinesterase activity in various areas and in the presynaptic cholinergic and the postsynaptic cholinoceptive enzyme-positive structures in the human and rat brain, Neuroscience, 101, 89-100 (2000).

[2] R. T. Bartus, R. L. Dean III, B. Beer, A. S. Lippa, The cholinergic hypothesis of geriatric memory dysfunctions. Science, 217, 408-417 (1982).

[3] A. Singh, Alzheimer's disease Inhibitors: Current status and future prospects. Int. J. Pharmaceutical Life Sci., 5, 3734-3740 (2014).

[4] A. Badia, J. E. Banos, P. Camps, Synthesis and evaluation of tacrine-huperzine A hybrids as 
acetylcholinesterase inhibitors of potential interest for the treatment of Alzheimer's disease. Bioorg. and Med. Chem., 6, 427-440 (1998).

[5] S. Roman, A. Badia, P. Camps, M. V. Clos, Potentiation effects of (+/-)huprine $\mathrm{X}$, a new acetylcholinesterase inhibitor, on nicotinic receptors in rat cortical synaptosomes. Neuropharmacology, 46, 95-102 (2004).

[6] A. Castro, A. Martinez, Peripheral and dual binding site acetylcholinesterase inhibitors: implications in treatment of Alzheimer's disease. Mini Rev. Med. Chem. 1, 267272 (2001)

[7] H. Sugimoto, H. Ogura, Y. Arai, Y. Iimura, Y. Yamanishi, Research and development of donepezil hydrochloride, a new type of acetylcholinesterase inhibitor, Jap. J. Pharmacol., 89, 7-20 (2002).

[8] R. N. Butler, Recent advances in tetrazole chemistry, Adv. Heterocycl. Chem., 21, 323-435 (1977).

[9] J. Roh, K. Vávrová, A. Hrabálek. Synthesis and Functionalization of 5-Substituted Tetrazoles, Eur. J. Organic Chem., 6101-6118 (2012).

[10] A. Dişli, G. D Celik, Y. Oner, L. Açık, Synthesis of some novel amino and thiotetrazole purine derivatives and investigation of their antimicrobial activity and DNA interactions, Med. Chem. Res., 22, 1470-1479 (2013).

[11] R. C. Elderfield, Tetrazoles, Tetrazines and Purines and Related Ring Systems. New York, John Wiley \& Sons Inc. 2-105, 1981.

[12] T. L. Gilchrist, Pyrazoles, Triazoles, and Tetrazoles Heterocyclic Chemistry. Cambridge: Cambridge University Press, 195-204, 1976.

[13] P. L. Ornstein, M. B. Arnold, N. K. Allen, T. Bleisch, P. S. Borromeo, C. W. Lugar, J. D. Leander, D. Lodge, D. D. Schoepp, Structure-activity studies of 6(tetrazolylalkyl)-substituted decahydroisoquinoline-3carboxylic acid AMPA receptor antagonists. 1. Effects of stereochemistry, chain length and chain substitution, J. Med. Chem., 39, 2219-2231 (1996).

[14] R. J. Herr, 5-Substituted-1H-tetrazoles as carboxylic acid isosteres: Medicinal chemistry and synthetic methods, Bioorg. Med. Chem., 10, 3379-3393 (2002).

[15] S. Saglam, A. Disli, Y. Erdogdu, M. K. Marchewka, N. Kanagathara, B. Bay, M. T. Gulluoglu, Synthesis, characterization and theoretical studies of 5-(benzylthio)-1cylopentyl-1H-tetrazole, Spectrochim. Acta A. Mol. Biomol. Spectrosc., 135, 1011-1018 (2015).

[16] M. Prokopowicz, P. Młynarz, P. Kafarski. Synthesis of phosphonate derivatives of 2,3-dihydroindene, Tetrahedron Lett., 50, 7314-7317 (2009).
[17] L.-M. Yang, L. Shwu-Jiuan, Y. Tsang-Hsiung, L. KuoHsiung, Synthesis of indan derivatives as mechanismbased inhibitors of dopamine $\beta$-hydroxylase, Bioorg. and Med. Chem., 941-944 (1995).

[18] T. Neubert, A. S. Kawatkar, E. Martinborough, A. Termin U.S. Patent No. 605,174. Washington, D. C: U.S. Patent and Trademark Office, 2009.

[19] S. Y. Han, J. W. Lee, H. J. Kim, Y. J. Kim, S. W. Lee, Y. S. Gyoung, A Facile One-Pot Synthesis of 1substituted tetrazole-5-thiones, Bull. Korean Chem. Soc., 55-59 (2012).

[20] G. L. Ellmaan, K. D. Courtney, V. J. Andres, R. M. Featherstone, A new and rapid colorimetric determination of acetyl cholinesterase activity, Biochem. Pharmacol., 88-95, (1961).

[21] H. W. Altland Smiles, Rearrangement of 2-Tetrazolylthio-3-aminopyridines, J. Org. Chem., 3395-3399 (1976).

[22] E. C. Lieber, N. Pillai, R. D. Hites, The reaction of nitrous acid with 4-substituted-thiosemicarbazides, Can. J. Chem., 832-842 (1957).

[23] E. C. Lieber, J. Ramachandran, Isomeric 5-(Substituted)aminothiatriazole and 1-Substituted-Tetrazolinethiones, Can. J. Chem., 101-109 (1959).

[24] A. Scozzafava, P. Kalın, C. T. Supuran, I. Gulcin, S. H. Alwase, The impact of hydroquinone on acetylcholine esterase and certain human carbonic anhydrase isoenzymes (hCA I, II, IX, and XII), J Enzyme Inhib Med Chem., 941-947 (2015).

[25] H. Dvir, I. Silman, M. Harel, T. L. Rosenberry, J. L. Sussman, Acetylcholinesterase: From 3D Structure to Function, Chem. Biol. Interact., 187, 10-22 (2010).

[26] V. Tello-Franco, M. C. Lozada-García, M. SorianoGarcía, Experimental and computational studies on the inhibition of acetylcholinesterase by curcumin and some of its derivatives, Curr. Comput. Aided Drug Des., 9, 289-298 (2013).

[27] S. Liu, R. Shang, L. Shi, R. Zhou, J. He, D. C Wan, Design, synthesis, and evaluation of $7 \mathrm{H}$-thiazolo-[3,2b]-1,2,4-triazin-7-one derivatives as dual binding site acetylcholinesterase inhibitors. Chem. Biol. Drug Des., 84, 169-174 (2014).

[28] E. Aynac1, Ph.D, Gazi University Graduate School of Natural and Applied Sciences, TR 2015.

[29] H.-R. Liu, X.-Q. Huang, D.-H. Lou, X.-J. Liu, W.-K. Liu, Q.-A. Wang, Synthesis and acetylcholinesterase inhibitory activity of Mannich base derivatives flavokawain B, Bioorg Med Chem. Lett., 22, 6124-6131 (2014). 